\title{
Three-Dimensional Analysis of Gate-Entry Stability in Multiple Seams Longwall Coal Mine Under Weak Rock Conditions
}

\author{
Pisith Mao ${ }^{1}$, Takashi Sasaoka ${ }^{1}$, Hideki Shimada ${ }^{1}$, Akihiro Hamanaka ${ }^{1}$, Sugeng Wahyudi ${ }^{1}$, Jiro Oya ${ }^{2} \&$ Naung Naung ${ }^{1}$ \\ ${ }^{1}$ Kyushu University, Fukuoka, Japan \\ ${ }^{2}$ MM Nagata Coal Tech Co., Ltd. Tokyo, Japan \\ Correspondence: Pisith Mao, Kyushu University, Faculty of Engineering, 744 Motooka, Nishi Ward, Fukuoka, Japan. \\ E-mail: mao17r@mine.kyushu-u.ac.jp
}

Received: December 16, 2019

doi:10.5539/esr.v9n1p72
Accepted: January 21, 2020

Online Published: January 30, 2020

URL: https://doi.org/10.5539/esr.v9n1p72

\begin{abstract}
A study of multiple seams longwall mining is proposed to investigate its applicability in Indonesia coal mine. The study area of this research is PT Gerbang Daya Mandiri (GDM) coal mine located in East Kalimantan Island. The study of seam interaction is crucial for developing multiple seams longwall mining especially when it comes to weak rock conditions which are usually found in most of the coal reserves in Indonesia. This paper will use numerical simulation to investigate the effect of the first mined-out seam on the development of the second coal seam gate-entry by considering a couple of key parameters including depth of the coal seam and interburden length. The simulation model consists of two main indicators for instability which include failure zone, the contour of safety factor. The results show that the effect of seam interaction on gate-entry has different intensity based on the thickness of the interburden and coal seam depth. This work also provided appropriate support configuration for maintaining the stability of gate-entry.
\end{abstract}

Keywords: numerical analysis, weak rock conditions, FLAC3D, multiple seams mining, seam interaction

\section{Introduction}

Indonesia is among one of the biggest coal export countries in the world because of the huge amount of coal resource available in the country. For many decades, Indonesia coal is recovered using surface mining methods. However, shallow coal seam for surface mining is depleting. As a result, mining industry starts to propose the study of underground mining development to extract coal in the deeper seam. Figure 1 shows the location map of PT Gerbang Daya Mandiri (GDM) and the surrounding coal mines. Based on the analysis of a series of drill-holes data, the geological structure of that area is monocline which contains many coal seams with the dip and thickness from $3^{\circ}$ to $13^{\circ}$ and from $0.15 \mathrm{~m}$ to $9.80 \mathrm{~m}$ respectively. Coal seams are surrounded by weak rock mass. The dominant rocks in the area are mostly claystone with thin layers of sandstone. Multiple seam longwall coal development is proposed to study in order to maximize coal recovery. Two coal seam is targeted. The first coal seam is seam BC which has $3.39 \mathrm{~m}$ to $9.80 \mathrm{~m}$ thickness. Another is seam $\mathrm{F}$ which has $0.7 \mathrm{~m}$ to $6 \mathrm{~m}$ thickness. Figure 2 illustrates the stratigraphy column that represents the general rock formation in the research area. This column is associated with Pulau Balang formation and Balikpapan formation which is aged between middle to upper Miocene (Widodo et al., 2010). In the study area, the shallowest seam 5 can be seen in the average depth of $100 \mathrm{~m}$ from the surface.

Developing multiple seam longwall mining is quite a big challenge for engineers. The first mined-out seam induces strata movement which led to the redistribution of stress surrounding the mined area (Guo et al., 2012; Suchowerska et al., 2013). This will affect the development of the second seam through the influence of seam interaction from the first mined-out seam. As a result, seam interaction is widely considered to be the most important in multiple seam mining development. According to Mark (2007), the intensity of seams interaction is correlated with several key factors which include: depth of the cover, mining sequence, interburden thickness and type of remnant structure. Undermining sequence is the most common practice for developing new multiple seam mining as the majority of the strata movement and other geotechnical concerts happen above the mined-out area (Ghabraie, 2016; Zipf, 2005). For this reason, undermining is adopted for this research. Both seams are excavated by longwall mining method. A few research have already been done in Indonesia coal resources for appropriated longwall development (Phanthoudeth et al., 2016; Pongpanya, Sasaoka, Shimada, Hamanaka, et al., 2017; Pongpanya, Sasaoka, Shimada \& Wahyudi, 2017; Sasaoka et al., 2015). However, previous work has been limited to single seam longwall development. This paper seeks to address the effect of the first seam longwall mined-out on the new gate development in the second seam. This research will consider 
two main key factors of seam interaction including the depth of the coal seam and the interburden thickness.

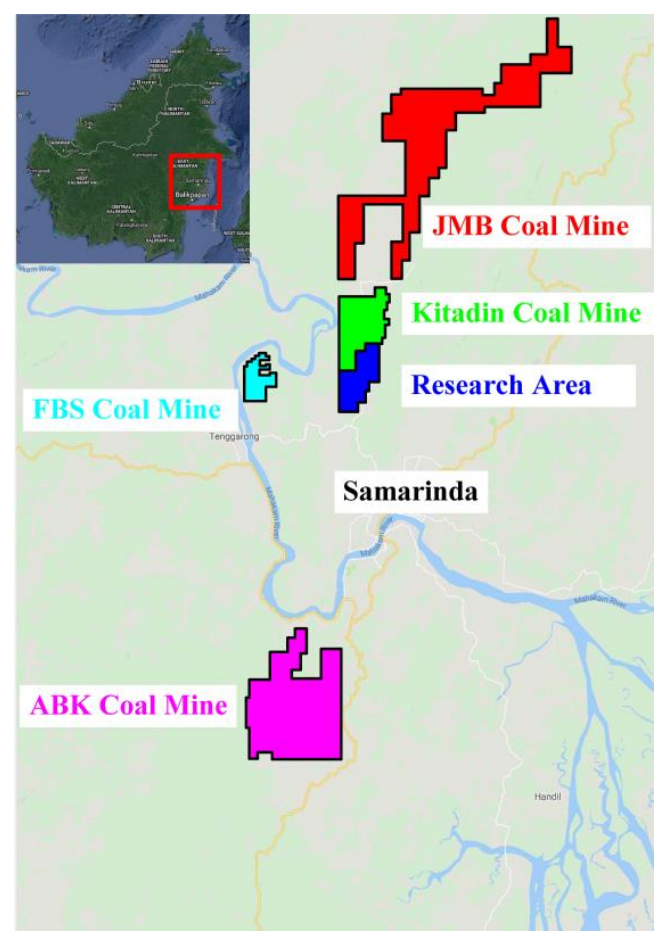

Figure 1. Location map of the research area

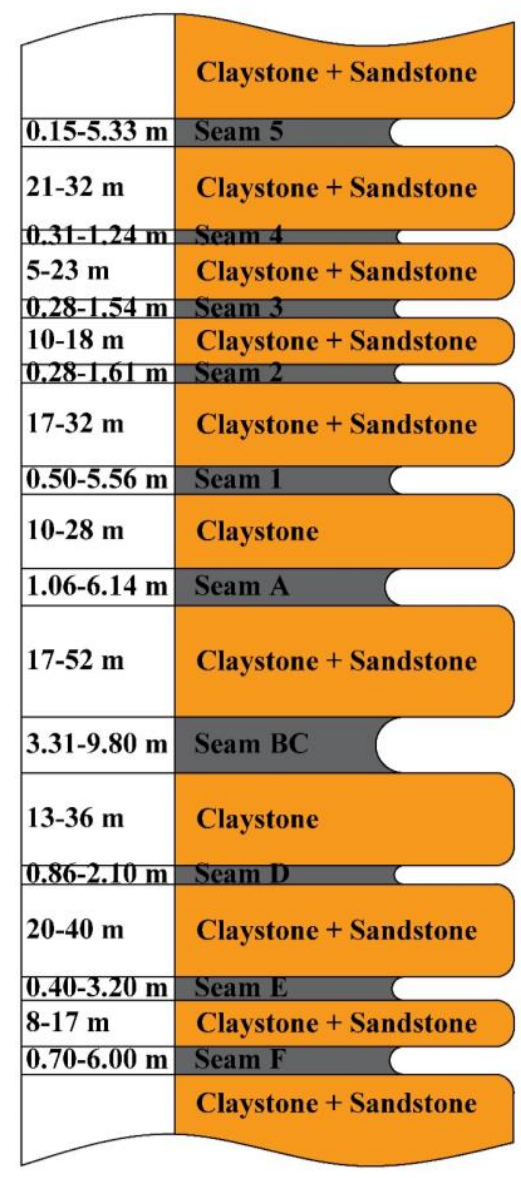

Figure 2. General stratigraphy column of the study area 


\section{Numerical Analysis}

FLAC3D is used in numerical analysis to identify the behavior of the rock after the excavation. This is a three-dimensional explicit finite-difference program which is designed for engineering mechanics computational. Material is introduced as zone element characterized by three-dimensional grid that can be constructed to fit the user's needs. Linear and nonlinear law of stress/strain is given to allow each element to behave responding to the boundary condition. The simulation model consists of two main indicators of instability which include failure zone and contour of safety factor. Failure zone is indicated when the stress satisfies the yield criterion which falls into two types of failure mechanism including shear failure and tension failure(Itasca_Consulting_Group, 2012). Safety factor contour is calculated from the Mohr-Coulomb shear failure criterion. However, an additional tension cut-off condition is applied in order to generate a more realistic result.

\subsection{Safety Factor Calculation From Mohr-Coulomb Failure Criterion With a Tension Cut-Off}

The factor of safety of certain locations in the rock can be estimated using the Mohr-Coulomb failure criterion with the availability of major and minor principal stress at that location (Kwon et al., 2013). Figure 3 shows the technique to calculate safety factor using this failure criterion. From this method, the following equation 1 can be written for estimating safety factor SF. OB is the distance from any point of the shear stress coordinate to the failure envelop. This distance represents the strength of the material. OA, on the other hand, is the mean stress between the major and minor principal stress. This represents the stress act on the material. So this equation is based on the ratio of strength divided by stress where $\sigma_{1}$ and $\sigma_{3}$ are major and minor principal stresses, $\mathrm{C}$ is cohesion and $\varphi$ is friction angle.

$$
S F=\frac{O B}{O A}=\frac{\left[\frac{\sigma_{1}+\sigma_{3}}{2}+\frac{C}{\tan \varphi}\right] \sin \varphi}{\frac{\sigma_{1}-\sigma_{3}}{2}}
$$

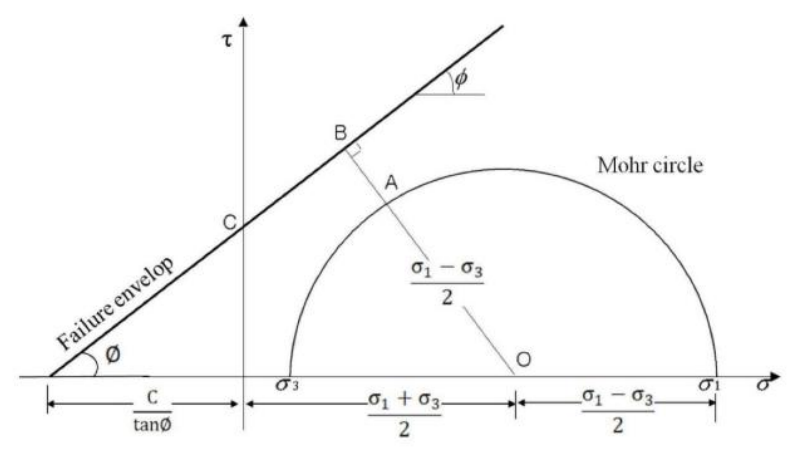

Figure 3. Factor of safety by Mohr-Coulomb failure envelope

The rock in the model is considered to have failed not only in shear mode but also in tension mode. Tension cut-off is applied to the previous Mohr-Coulomb failure envelope. As shown in Figure 4, the rock failed in shear mode if the stress condition follows the Mohr-Coulomb failure criterion. In addition, when the minor principal stress is surpassed the tensile strength of the rock, it is considered to have failed in tension mode (Xu et al., 2015).

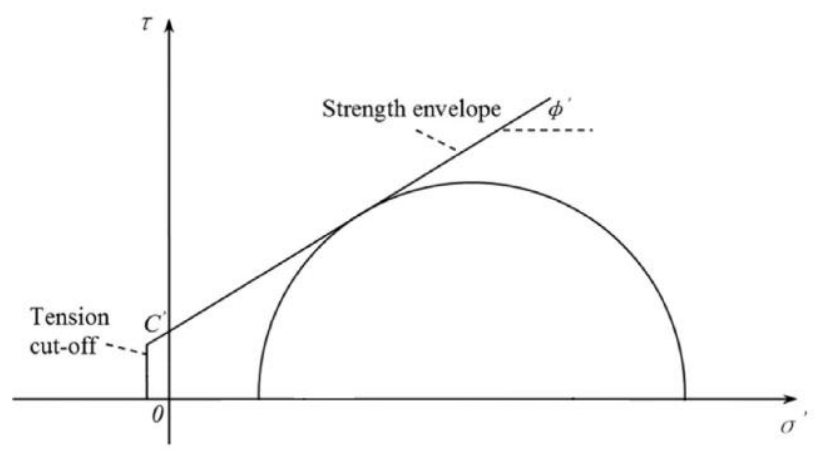

Figure 4. Mohr-Coulomb with tension cut-off 


\subsection{Model Description}

Figure 5 illustrated the overall model dimension used to analyses the influence of the mined-out area in the first seam to the new development entry gateway of the second lower seam. In the model, two coal seams with a thickness of $3 \mathrm{~m}$ are separated by claystone as the interburden. Both overburden and underburden are considered to be claystone as well. The depths of the second seam are modeled to be $150 \mathrm{~m}, 200 \mathrm{~m}$ and $300 \mathrm{~m}$. The thickness of interburden is varied from $30 \mathrm{~m}$ to $90 \mathrm{~m}$ with an incremental length of $10 \mathrm{~m}$. The panel dimensions are $100 \mathrm{~m} \times 200 \mathrm{~m}$ and chain pillar widths are fixed base on the depth of the second seam which are $30 \mathrm{~m}, 45 \mathrm{~m}$ and $75 \mathrm{~m}$ for the depth of $150 \mathrm{~m}, 200 \mathrm{~m}$ and $300 \mathrm{~m}$ respectively. The gate entry is horseshoe-shaped tunnel with $5 \mathrm{~m}$ width and $3 \mathrm{~m}$ height. Steel arch and cable bolt are used to support gate-entry roof and floor respectively. Figure 6 demonstrates the installation support in the model.

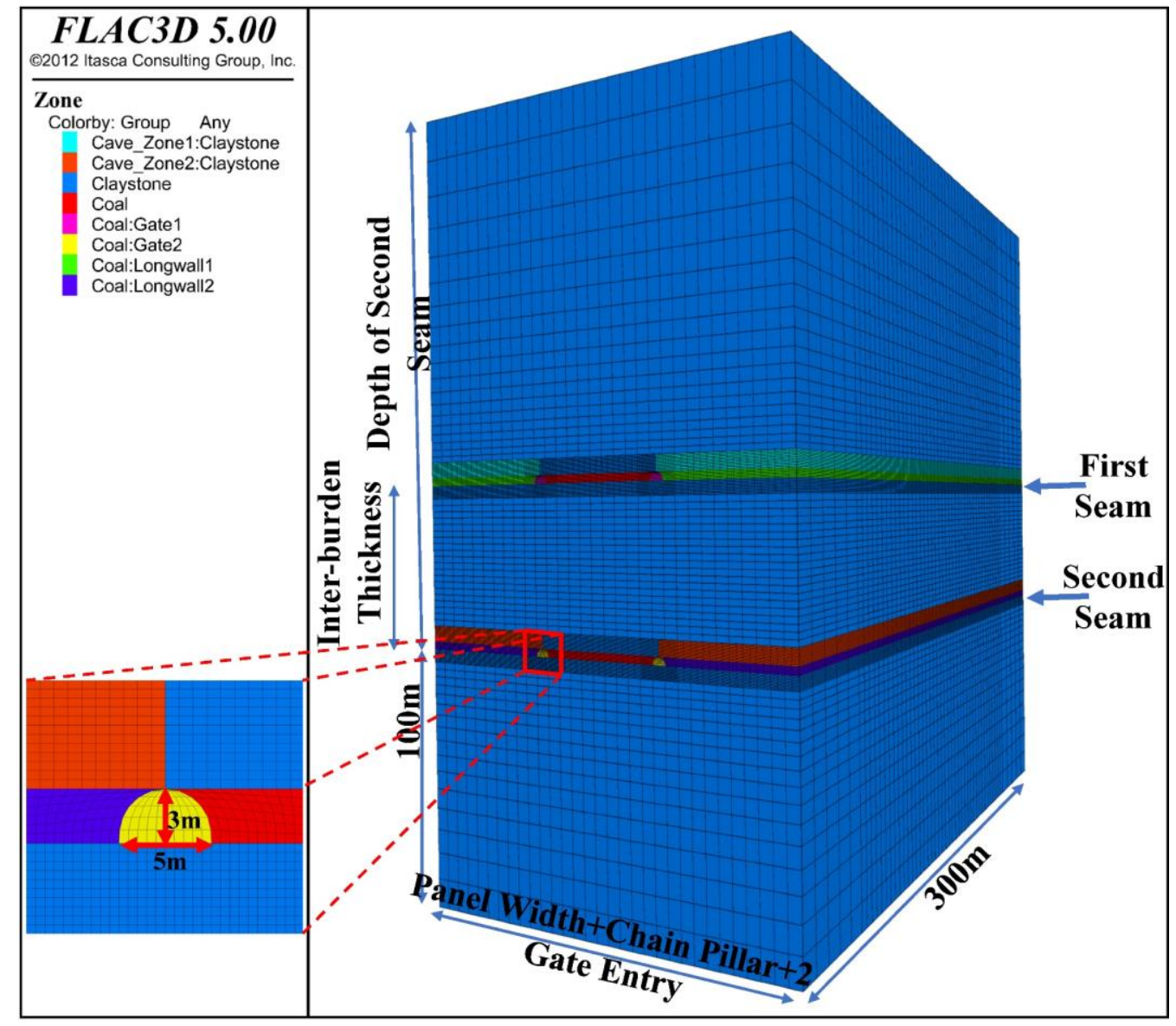

Figure 5. General model dimensions

The excavation steps of the model are included:

- Construction model geometry with two coal seams ( based on theories of symmetrical in numerical simulation, each seam contain two halves of panel width with two gates and a chain pillar in the middle)

- Applying boundary conditions by restricted horizontal movement in the direction perpendicular to each side of the model and vertical movement at the bottom of the model. Because this model simulated the rock up to the surface, there is no movement restriction on the top part of the model.

- Assigning mechanical properties of rocks and initial stress conditions.

- Analyzing for the initial state

- Excavating the first seam gate entry and installation of support for $200 \mathrm{~m}$

- Operating panel extraction in the first seam for both panel for $200 \mathrm{~m}$

- Excavating the second seam gate entry (without support for investigating seam interaction and with support for identifying appropriated support)

- Monitoring failure zone and contour of safety factor.

Mechanical properties of the rock and supports used in the simulation are shown in tables 1,2 and 3 respectively. Models in the study adopt Mohr-Coulomb plasticity as a constitutive model. The stress ratio is designated to be 1 . 


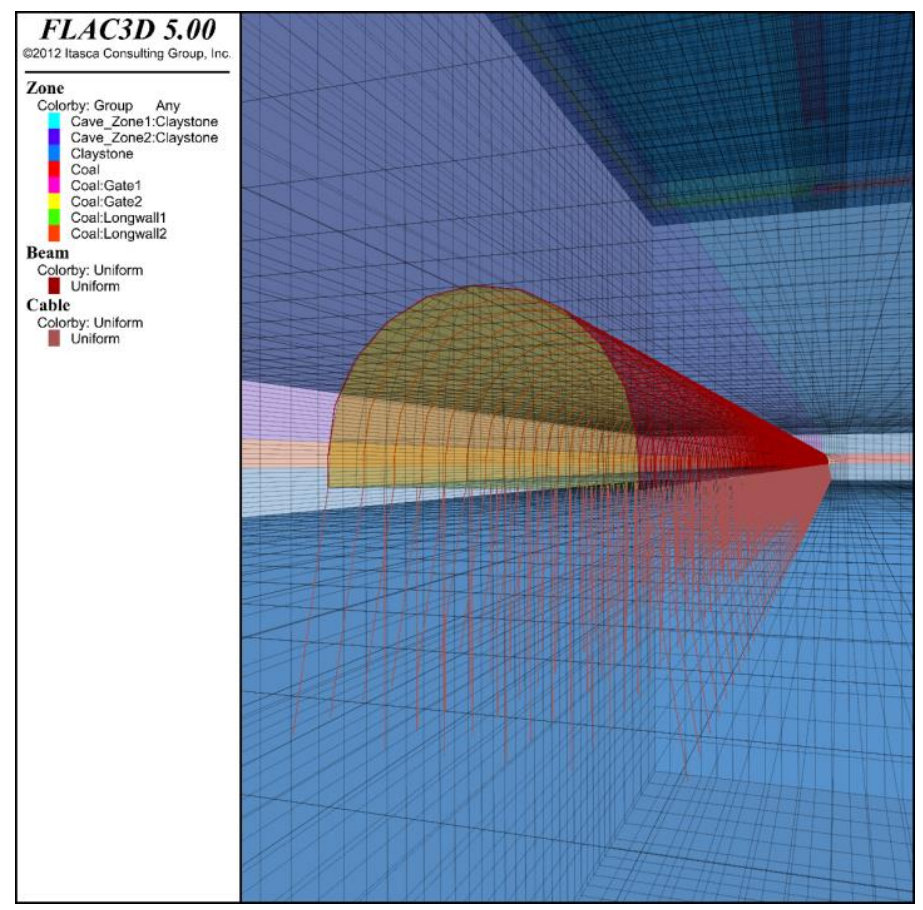

Figure 6. Modelling support system

Table 1. Mechanical properties of rocks

\begin{tabular}{ccccccc}
\hline Rock & $\begin{array}{c}\text { UCS } \\
(\mathrm{MPa})\end{array}$ & $\begin{array}{c}\text { Density } \\
(\mathrm{kg} / \mathrm{m} 3)\end{array}$ & $\begin{array}{c}\text { Young Modulus } \\
(\mathrm{MPa})\end{array}$ & $\begin{array}{c}\text { Poisson's } \\
\text { Ratio }\end{array}$ & $\begin{array}{c}\text { Friction Angle } \\
\left({ }^{\circ}\right)\end{array}$ & $\begin{array}{c}\text { Cohesion } \\
(\mathrm{MPa})\end{array}$ \\
\hline Claystone & 10.49 & 2140 & 2324.68 & 0.27 & 37.48 & 0.56 \\
Coal & 8.16 & 1380 & 1295.8 & 0.25 & 45.66 & 2.63 \\
Goaf & - & 1700 & 15 & 0.25 & 25 & 0.001 \\
\hline
\end{tabular}

Table 2. Mechanical properties of steel arch support

\begin{tabular}{cccccc}
\hline Type & $\begin{array}{c}\text { Dimension } \\
(\mathrm{mm})\end{array}$ & $\begin{array}{c}\text { Young Modulus } \\
(\mathrm{GPa})\end{array}$ & Poisson's Ratio & $\begin{array}{c}\text { Cross-Sectional } \\
\text { Area }(\mathrm{cm} 2)\end{array}$ & $\begin{array}{c}\text { Yield Strength } \\
(\mathrm{MPa})\end{array}$ \\
\hline JIS 3010 & $95 \times 115$ & 200 & 0.3 & 36.51 & 540 \\
\hline Table 3. Mechanical properties of cable bolt & & & & \\
\hline Type & Length & Diameter & Young Modulus & Tension Capacity \\
& $(\mathrm{m})$ & $(\mathrm{mm})$ & $(\mathrm{GPa})$ & 0.1 \\
\hline Fully Grouted & 3.5 & 19 & 200 & \\
\hline
\end{tabular}

\section{Results and Discussions}

\subsection{Seam Interaction on Gate Entry}

Seam interaction in multiple seam longwall development can be described in the form of influence on the stability of the first mined-out seam to the current development seam. For this research, the influence is identified by observing the increment of the failure zone. Plasticity model in FLAC3D, failure has occurred when stress satisfies yield strength criterion in which failure mechanism can arise in shear failure and tensile failure (Itasca_Consulting_Group, 2012; Zarlin et al., 2012). The single seam model is also constructed and analyzed for each depth. The results from the single seam model are adopted as a control sample to compare the result with multiple seams models in order to identify the influence of seam interaction. 


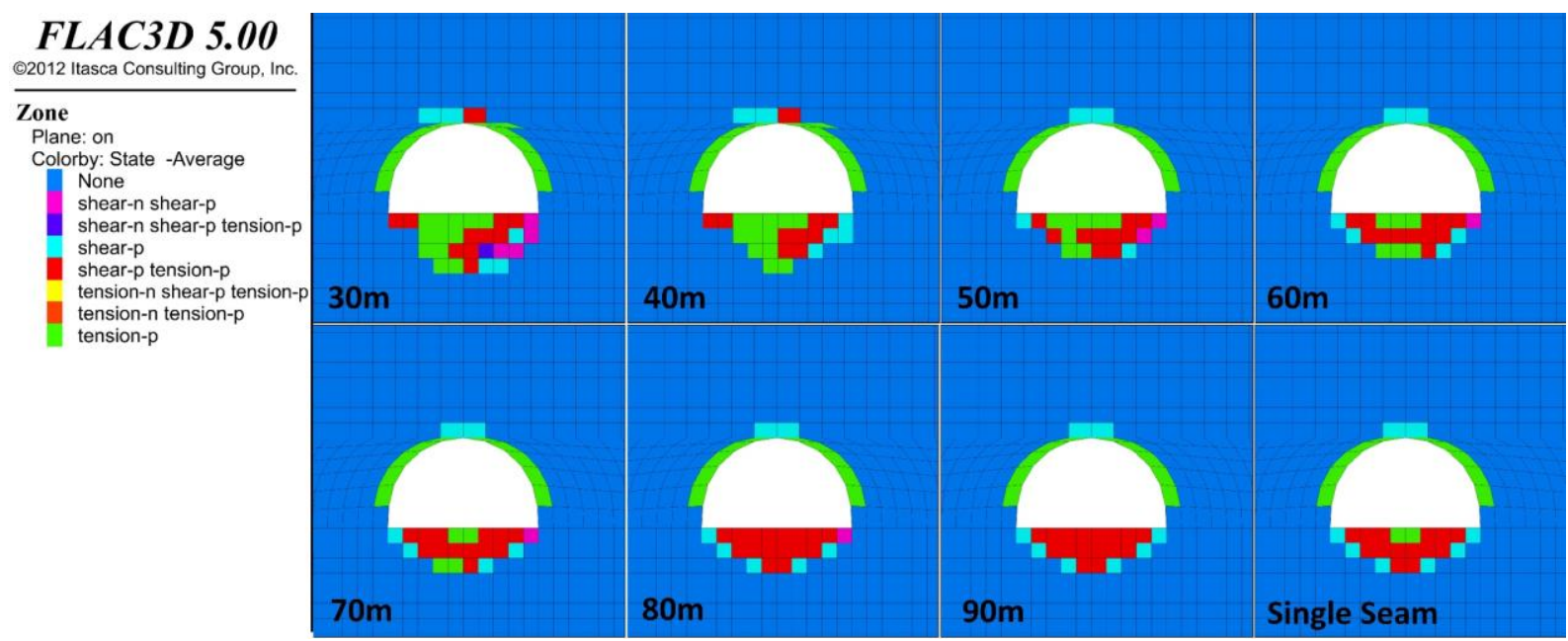

Figure 7. Failure zone around the excavation of the gate entry with various interburden thickness (150m depth)

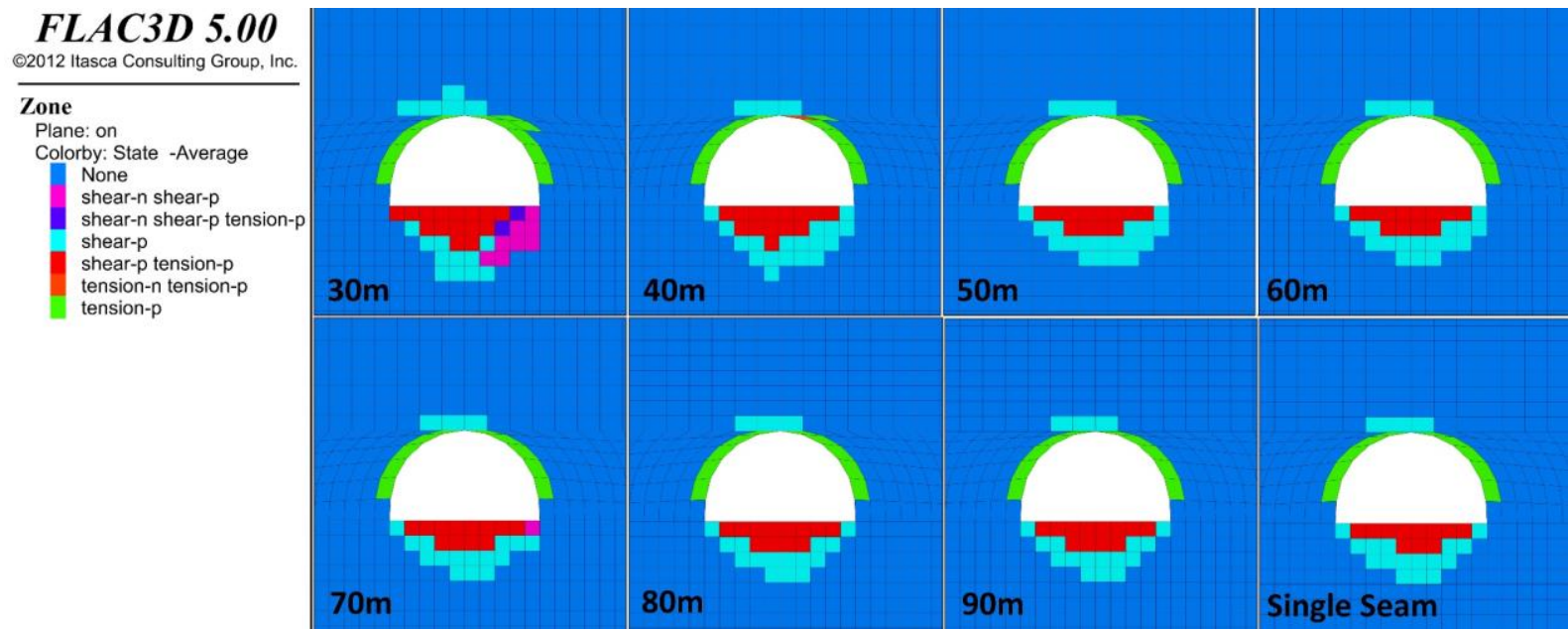

Figure 8. Failure zone around the excavation of the gate entry with various interburden thickness (200m depth)

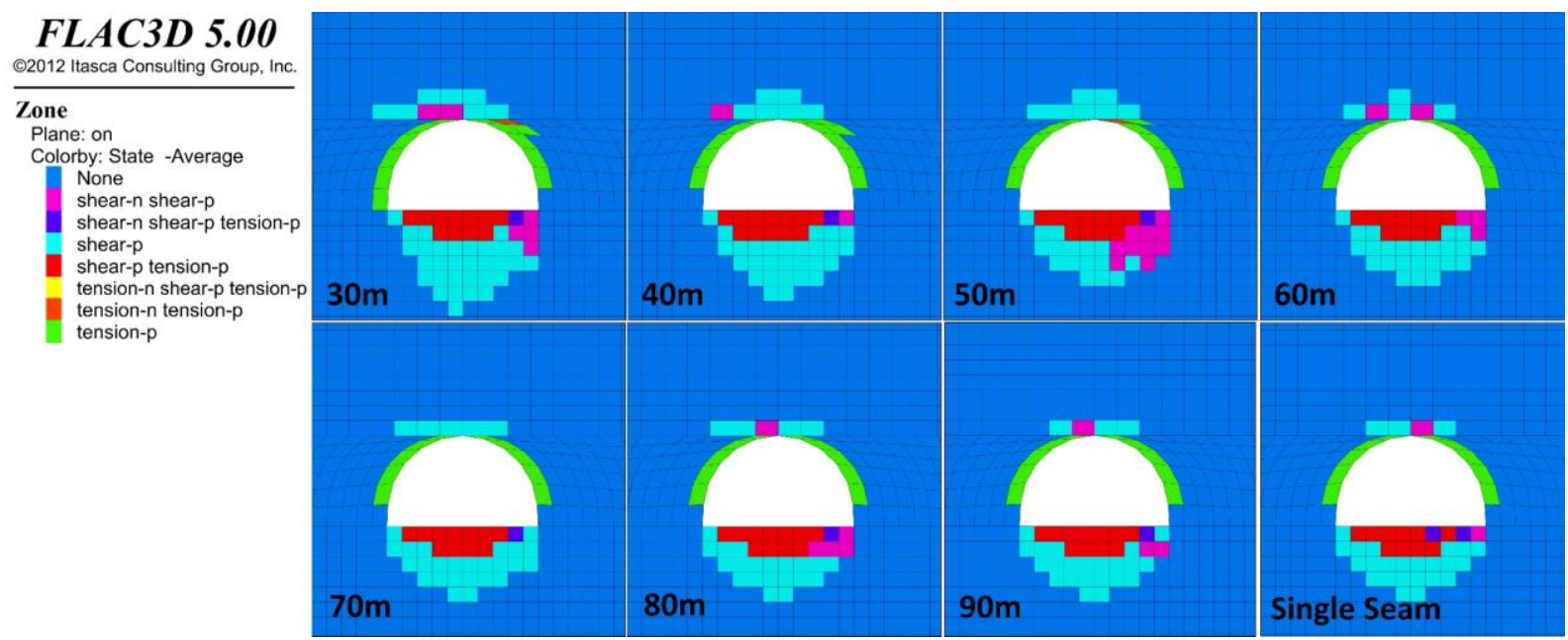

Figure 9. Failure zone around the excavation of the gate entry with various interburden thickness (300m depth)

Figure 7 shows the development of the failure zone around the excavation of the gate entry without any support system for the depth of $150 \mathrm{~m}$ with various interburden thickness. From this result, it can be observed that the floor failure zone is more severe than the roof. The thinnest interburden of $30 \mathrm{~m}$ shows a deeper and wider instability zone compared to the gate entry developed in a single seam longwall system. It clearly shows the influence of the previous mined-out seam. The influence of the mined-out seam is decreased as the thickness of interburden increases. This seam interaction for $150 \mathrm{~m}$ 
depth seems to be able to reach only $60 \mathrm{~m}$ of interburden thickness as the failure zone of begin from $70 \mathrm{~m}$ thickness is identical to those of single seam development at the same depth.

A similar condition can be observed for depth $200 \mathrm{~m}$ and $300 \mathrm{~m}$. According to the results obtained from these simulations, more severe failure present in deeper coal seam cases. As shown in Figures 8 and 9, seam interaction seems to have surpassed to thicker interburden. For $200 \mathrm{~m}$ depth, the influence of the first mined-out seam can reach until $70 \mathrm{~m}$ thickness of interburden while additional failure still presents in $80 \mathrm{~m}$ interburden for $300 \mathrm{~m}$ depth.

\subsection{Installation of Support Systems}

The support system is installed in the model to stabilize the excavation of the gate-entry under the influence of the first mined-out seam. Two types of support are adopted to support gate entry include steel arch for the roof and cable bolt for the floor. There are 4 configurations of the support system as shown in Figure 10. Safety factor contour calculated from Mohr-Coulomb failure envelope with tension cut-off is the key indicator of the stability after the installation of the support system. The safety factor of 1.3 is considered to be the safe value in mining as it is widely adopted in many mine designs for temporary mine opening (Hoek et al., 2000).

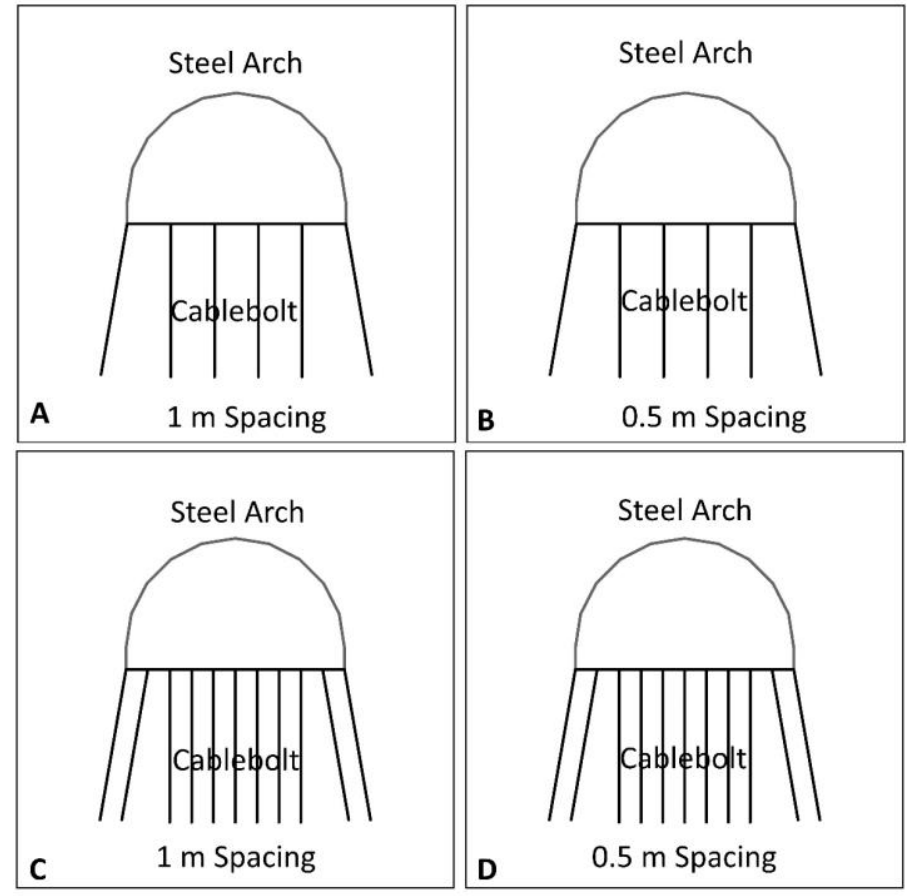

Figure 10. Variations of support system configurations

\begin{tabular}{l} 
FLAC3D 5.00 \\
O2012 tasca Consulting Group, Inc. \\
\hline Countour of Safety Factor \\
Plane: on \\
Calculated by: Volumetric Averaging \\
$1.3000 \mathrm{E}+00$ \\
$1.3000 \mathrm{E}+00$ \\
$1.2000 \mathrm{E}+00$ \\
$1.1000 \mathrm{E}+00$ \\
$1.0000 \mathrm{E}+00$
\end{tabular}
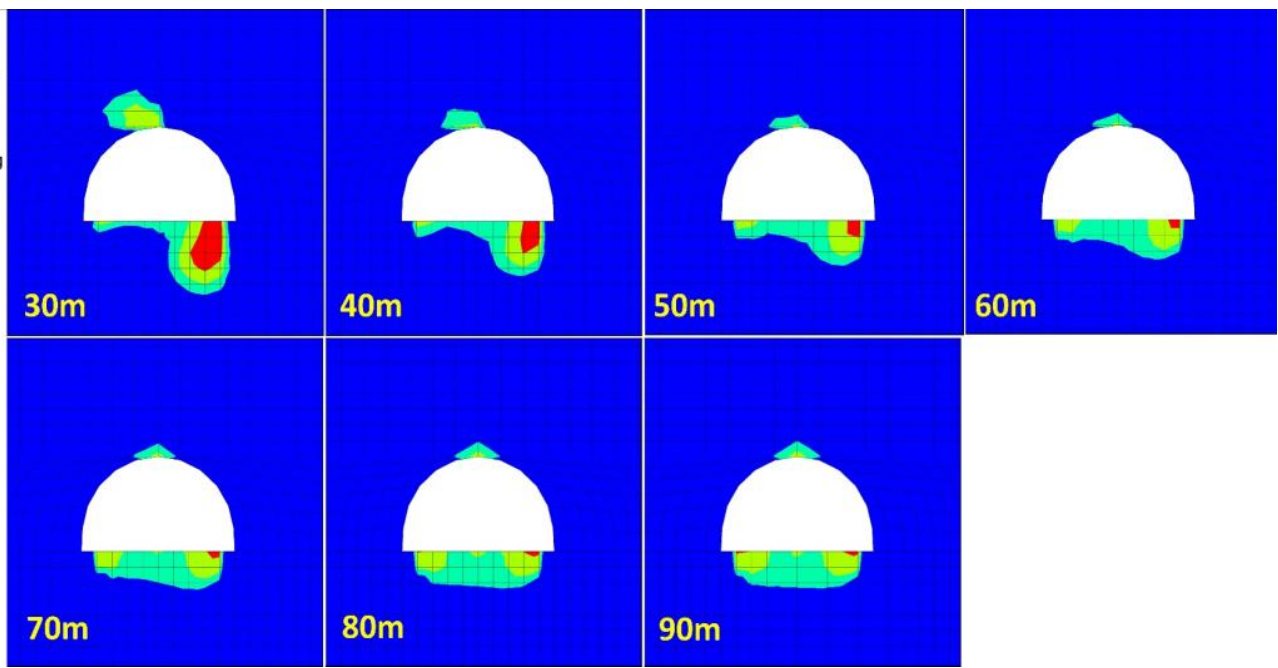

Figure 11. Factor of safety contour for support type A (150m depth) 
The result of investigating appropriated support for 150m depth is illustrated in Figure 11 to 14 for support type A to type D respectively. The safety factor contour revealed that support type A cannot be used to support the gate entry as it still generates a large area in which the value of the safety factor is less than 1.3. Support types B and C can effectively reduce the instability zone but not completely diminish it. Type D support provides the best result as it completely eliminates the instability area for the interburden thickness over $30 \mathrm{~m}$. For the thickness of $30 \mathrm{~m}$, the minimum failure zone can be seen. For the economical point of view, concerning the stability of the roof alone, it is plausible to adopt $1 \mathrm{~m}$ spacing of steel arch to support the gate entry roof for $150 \mathrm{~m}$ depth. As a result from Figures 11 and 13 show that the instability zone of the roof is very minimal and the value of safety factor of that instability zone is already above 1 . This overall result implied that support type D the array of steel arch and one set of 11 cable bolts with the spacing of $0.5 \mathrm{~m}$ provides the best support for the gate entry for $150 \mathrm{~m}$. Minimal instability zone can be seen in the interburden thickness is $30 \mathrm{~m}$. It is also plausible to adopt support type $\mathrm{C}$ for gate entry. However, it is not recommended to use with interburden thickness of $30 \mathrm{~m}$ as it shows a significant instability zone on the floor.

Support type C and D is adopted in the model for the depth $200 \mathrm{~m}$ and $300 \mathrm{~m}$ to identify the effectiveness of this support system to a different depth. Figures 15 and 16 show safety factor contour for $200 \mathrm{~m}$ depth. A similar trend to the previous result can be perceived. Figure 15 indicates that utilization of support type $\mathrm{C}$ is still plausible in $200 \mathrm{~m}$ depth in the case where the interburden is thicker than $30 \mathrm{~m}$ considering roof stability alone. In addition, figure 16 shows that support type $\mathrm{D}$ can be used to support the gate entry with the interburden above $30 \mathrm{~m}$.

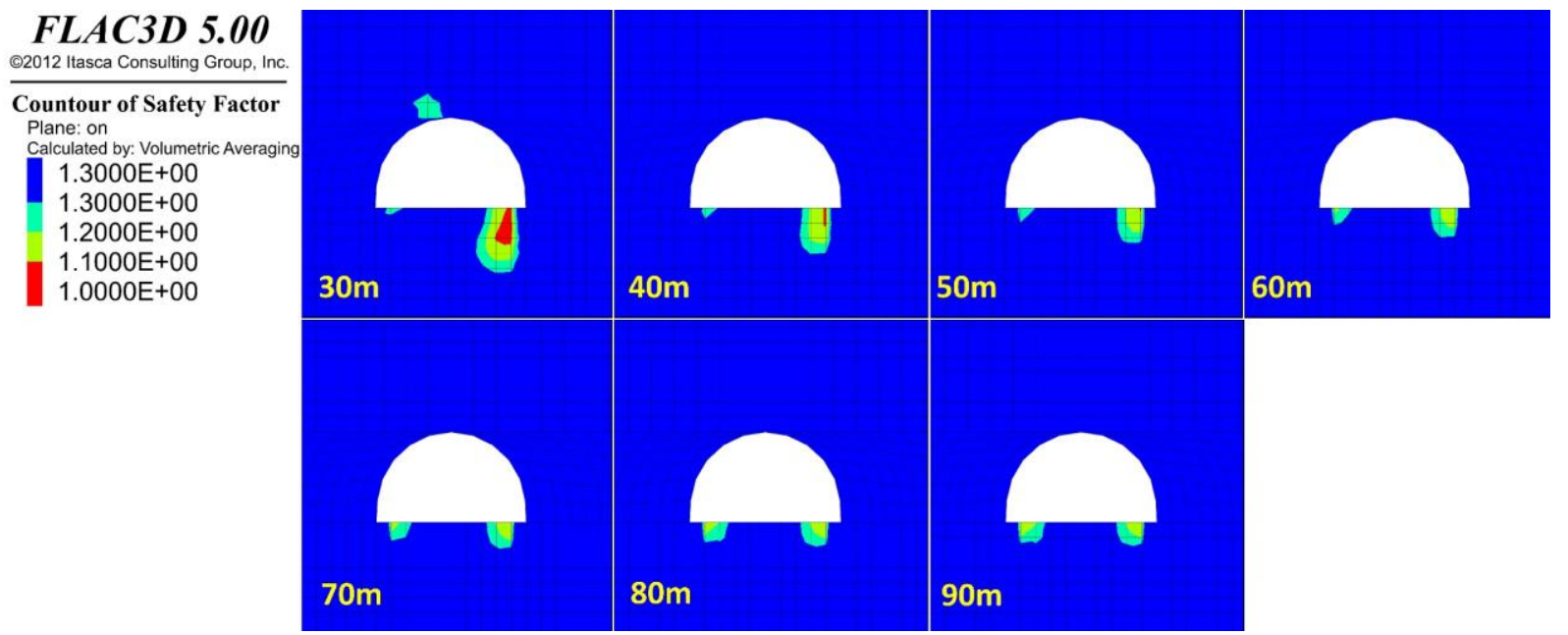

Figure 12. Factor of safety contour for support type B (150m depth)

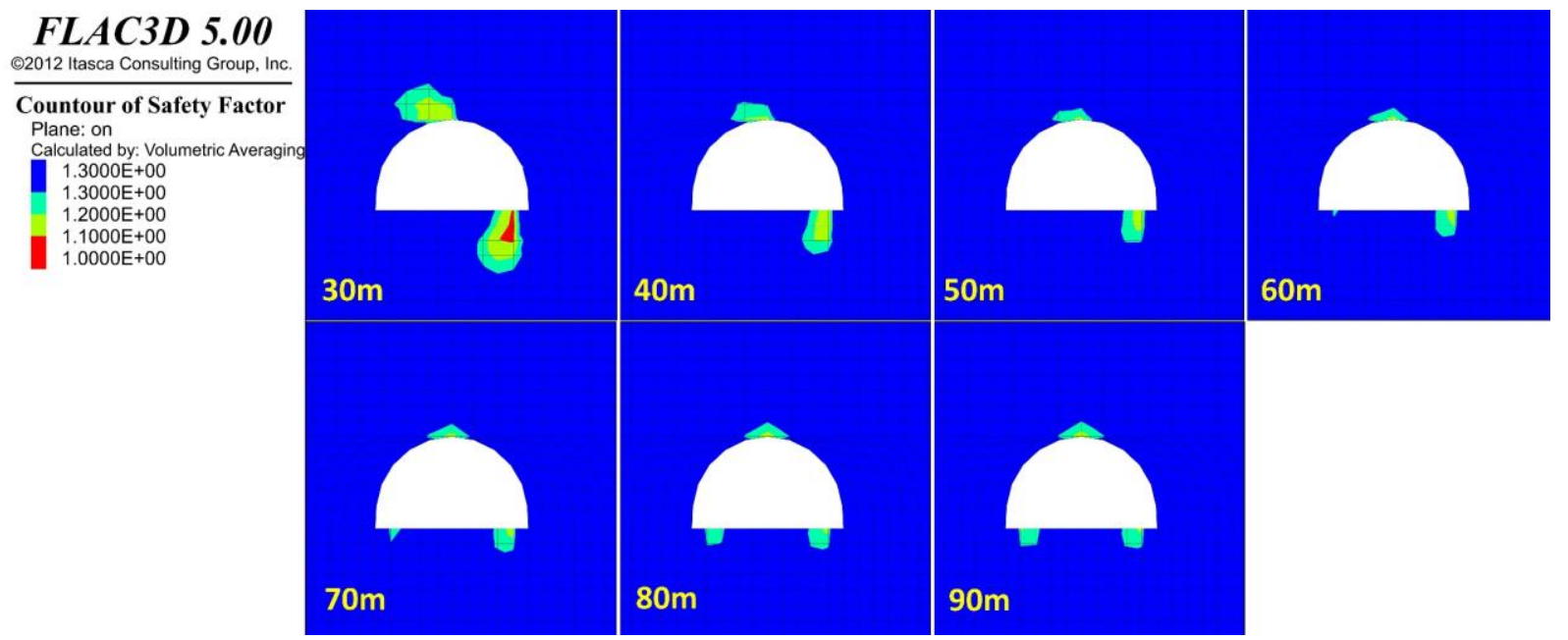

Figure 13. Factor of safety contour for support type C (150m depth) 


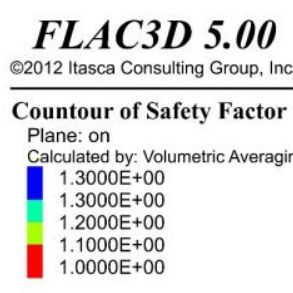

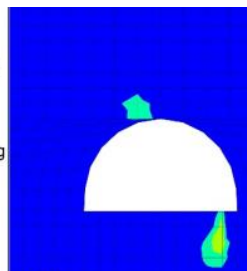

$30 \mathrm{~m}$

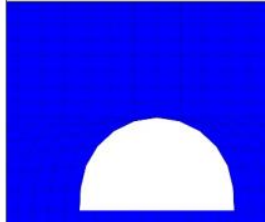

$70 \mathrm{~m}$
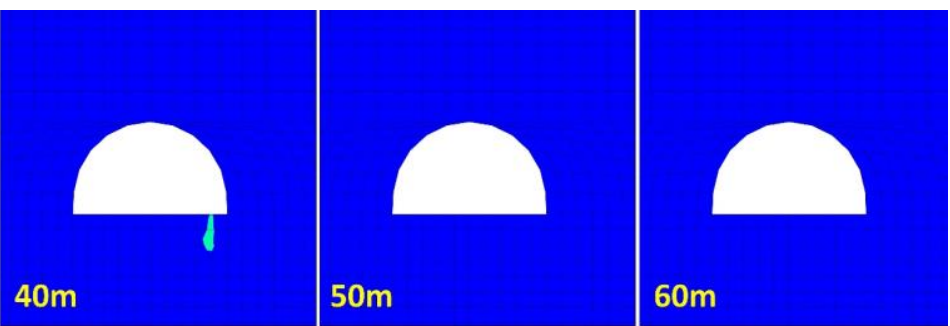

Figure 14. Factor of safety contour for support type D (150m depth)
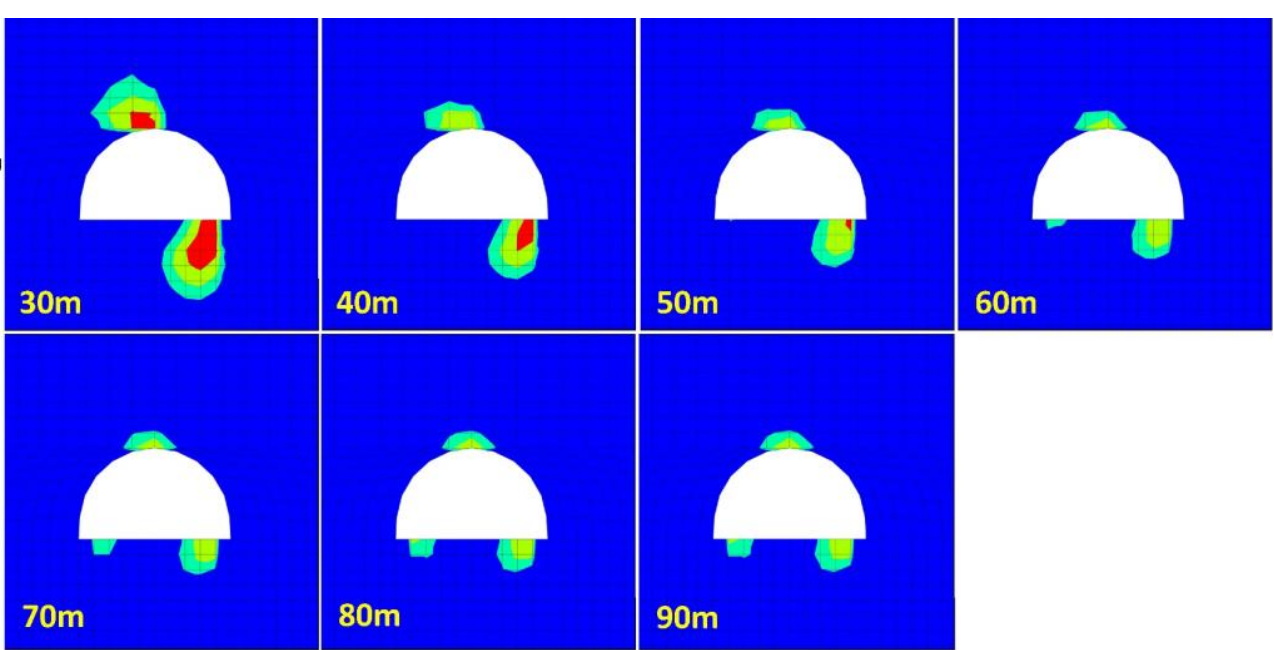

Figure 15. Factor of safety contour for support type C (200m depth)

\begin{tabular}{c}
$\boldsymbol{F L} \boldsymbol{A C 3 D} \mathbf{C . 0 0}$ \\
@2012 Itasca Consulting Group, Inc. \\
\hline Countour of Safety Factor \\
Plane: on \\
Calculated by: Volumetric Averaging \\
$1.3000 \mathrm{E}+00$ \\
$1.3000 \mathrm{E}+00$ \\
$1.2000 \mathrm{E}+00$ \\
$1.1000 \mathrm{E}+00$ \\
$1.0000 \mathrm{E}+00$
\end{tabular}

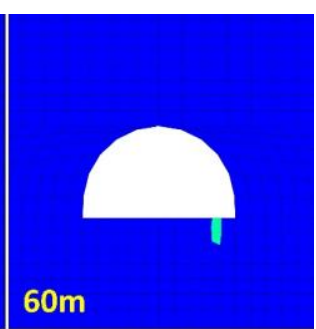

$60 \mathrm{~m}$

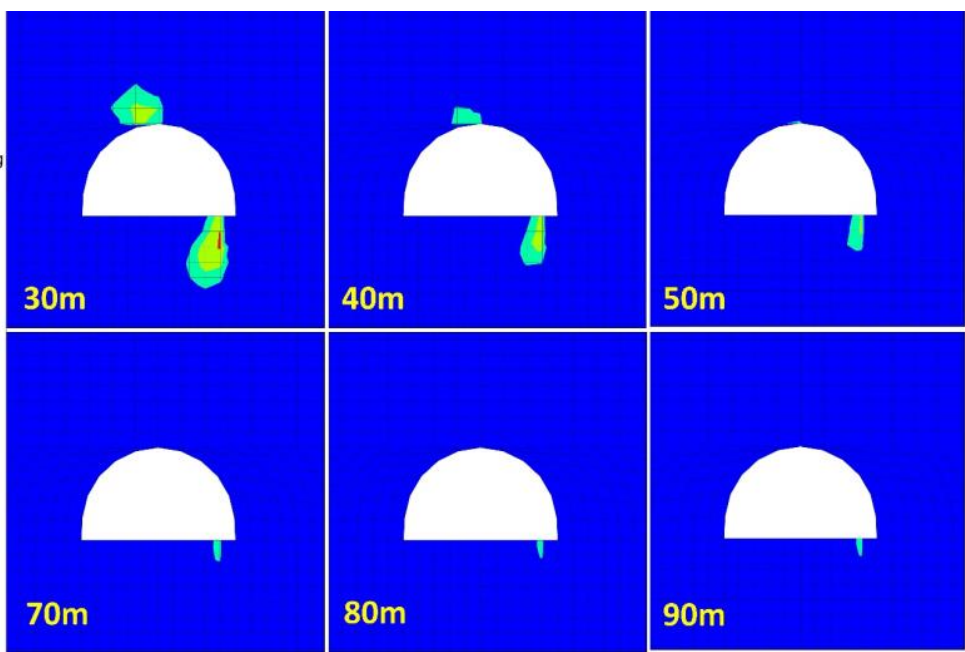

Figure 16. Factor of safety contour for support type D (200m depth) 

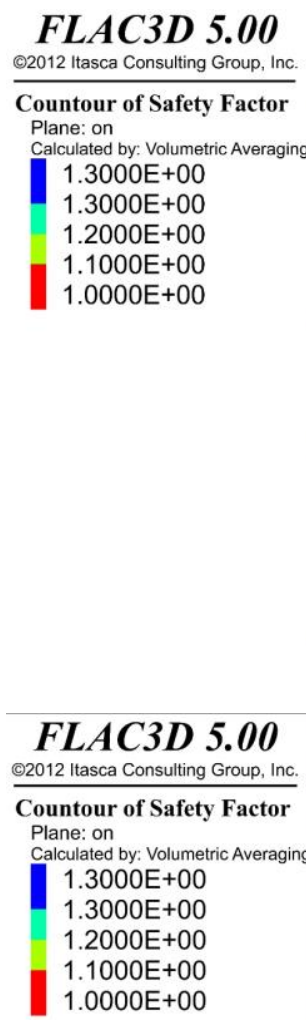
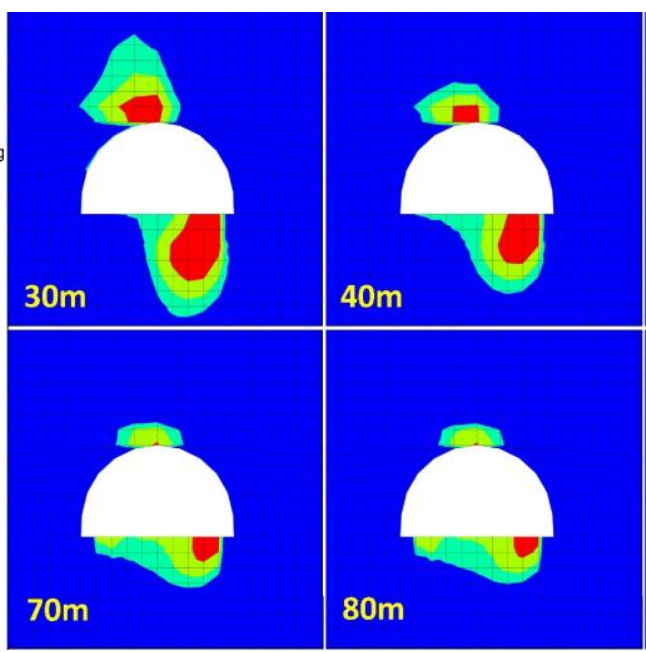

$50 \mathrm{~m}$
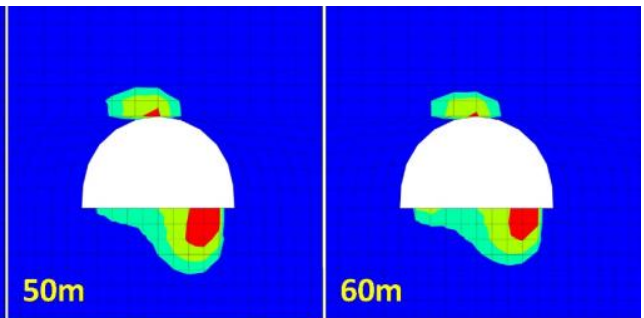

Figure 17. Factor of safety contour for support type C (300m depth)
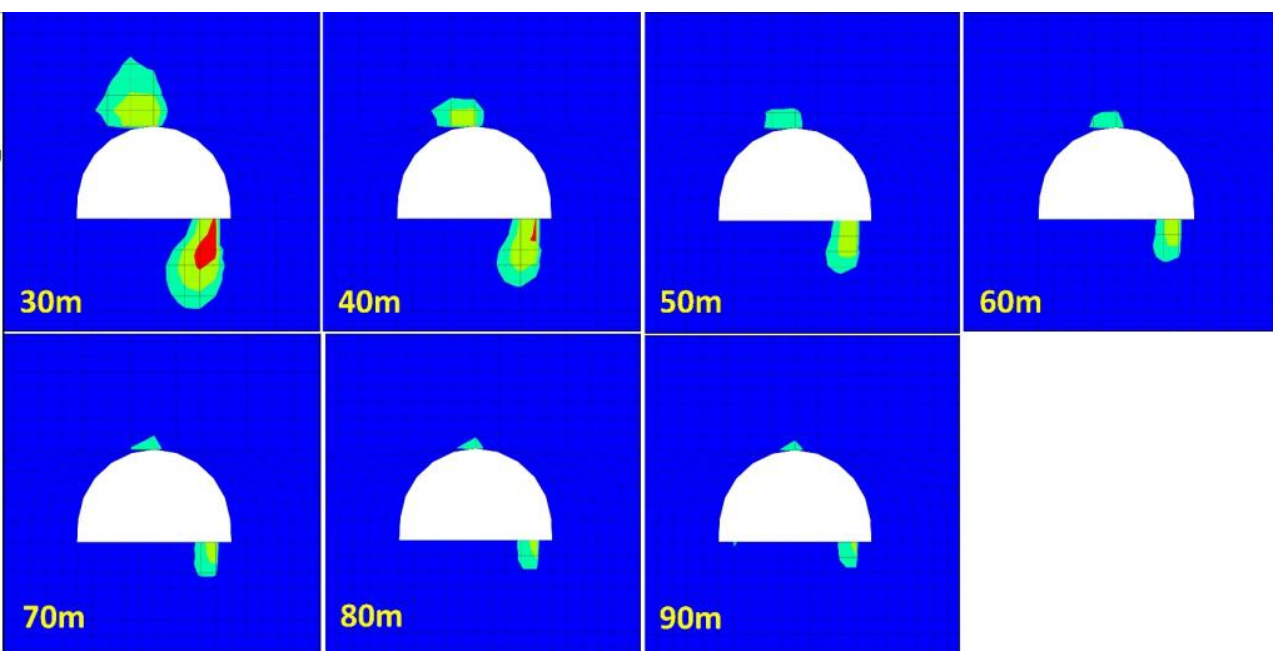

Figure 18. Factor of safety contour for support type D (300m depth)

Figures 17 and 18 are the simulated results for $300 \mathrm{~m}$ depth which shows a slight difference result. From these figures, it is believed that support type $\mathrm{C}$ is not suitable for utilizing in $300 \mathrm{~m}$ depth. Support type $\mathrm{D}$ is applicable for $300 \mathrm{~m}$ where the interburden is exceeded $40 \mathrm{~m}$. Support type D is not suitable for cases of $200 \mathrm{~m}$ depth with interburden less than $30 \mathrm{~m}$ and $300 \mathrm{~m}$ depth with interburden less than $40 \mathrm{~m}$. For these cases, it is recommended to extend the length of cable bolt for floor support and combine steel arch with rock bolt for roof support.

\section{Conclusions}

This paper has investigated seam interaction in multiple seams longwall development. The study had led to the conclusion that the influence of the first mined-out seam has different intensity based on the thickness of the interburden. Moreover, this influence can surpass thicker interbuden in deeper the coal seam. For $150 \mathrm{~m}, 200 \mathrm{~m}$ and $300 \mathrm{~m}$ depth coal seam the interaction between first mined-out seam to the new gate entry reach until interburden thickness of $60 \mathrm{~m}, 70 \mathrm{~m}$, and $80 \mathrm{~m}$ respectively.

The array of steel arch support with $1 \mathrm{~m}$ spacing is applicable for roof support up to $200 \mathrm{~m}$ depth except for the case of 200 $\mathrm{m}$ depth where the interburden is $30 \mathrm{~m}$. For $300 \mathrm{~m}$ depth, it is recommended to utilize a narrower $0.5 \mathrm{~m}$ spacing. For floor support, a set of 11 cable bolt with $3.5 \mathrm{~m}$ length installed in $1 \mathrm{~m}$ spacing is suitable for $150 \mathrm{~m}$ and $200 \mathrm{~m}$ depth with interburden more than $30 \mathrm{~m}$ and $50 \mathrm{~m}$ respectively. For $300 \mathrm{~m}$ depth, on the other hand, this configuration should be installed in $0.5 \mathrm{~m}$ spacing. Other thin case of interburden where it unsuitable to utilize support type $\mathrm{D}$, which include case 200 depth with $30 \mathrm{~m}$ interburden and $300 \mathrm{~m}$ depth with interburden less than $40 \mathrm{~m}$, it is suggestions to extend length of cable bolt for floor support and incorporate rock bolt with steel arch for roof support in order to minimize the unstable zone completely.

Cable bolt is very effective as floor support. However, if floor heaving happens, it is difficult to operate floor treatment as bolts ripping is required. In this case, fiber bolt or shallow timber piles are also recommended as they provide a slightly 
weak floor reinforcement effect but a much easy floor treatment operation.

According to site data, the competence of claystone is depth-dependent which is varied from softer to harder than coal seam. In some locations, coal thickness is thicker than the mining height. The future work should focus on the remain coal thickness effect on the stability of the gate. The research should be carried out for the location where claystone is softer than coal. It is believed that remain coal thickness can help improve the stability of gate entry which reduces the amount of support required.

\section{Acknowledgments}

This research is made possible under the financial support of JICA in AUN/SEED.Net program. The author also gratefully acknowledges PT Gerbang Daya Mandiri (GDM) coal mine, who provides valuable field data for this research work.

\section{References}

Ghabraie, B. (2016). Multi-seam mining-induced ground surface subsidence, characteristics and prediction. (Doctor of Philosophy), RMIT University.

Guo, H., Yuan, L., Shen, B., Qu, Q., \& Xue, J. (2012). Mining-induced strata stress changes, fractures and gas flow dynamics in multi-seam longwall mining. International Journal of Rock Mechanics and Mining Sciences, 54, 129-139. https://doi.org/10.1016/j.ijrmms.2012.05.023

Hoek, E., Kaiser, P. K., \& Bawden, W. F. (2000). Support of underground excavations in hard rock: CRC Press. https://doi.org/10.1201/b16978

Itasca_Consulting_Group. (2012). FLAC3D 5.0 manual: Itasca Consulting Group Minneapolis.

Kwon, S., Cho, W. J., \& Lee, J. O. (2013). An analysis of the thermal and mechanical behavior of engineered barriers in a high-level radioactive waste repository. Nuclear Engineering and Technology, 45(1), 41-52. https://doi.org/10.5516/NET.06.2012.015

Mark, C. (2007). Multiple-seam mining in the United States: background. Proceedings: new technology for ground control in multiple seam mining. US Department of Health and Human Services, Public Health Service, Centers for Disease Control and Prevention, National Institute for Occupational Safety and Health, Pittsburgh, DHHS (NIOSH) Publication(97-122), 3-14.

Phanthoudeth, P., Sasaoka, T., Shimada, H., Ulaankhuu, B., Oya, J., Dwiki, S., \& Karian, T. (2016). Numerical Study on Roadway Stability under Weak Geological Condition of PT Gerbang Daya Mandiri Underground Coal Mine in Indonesia. GSTF Journal of Geological Sciences (JGS), 3(1), 15-23.

Pongpanya, P., Sasaoka, T., Shimada, H., Hamanaka, A., \& Wahyudi, S. (2017). Numerical Study on Effect of Longwall Mining on Stability of Main Roadway under Weak Ground Conditions in Indonesia. Journal of Geological Resource and Engineering, 3, 93-104. https://doi.org/10.17265/2328-2193/2017.03.001

Pongpanya, P., Sasaoka, T., Shimada, H., \& Wahyudi, S. (2017). Study of Characteristics of Surface Subsidence in Longwall Coal Mine under Poor Ground Conditions in Indonesia. Earth Science Research, 6, 129. https://doi.org/10.5539/esr.v6n1p129

Sasaoka, T., Takamoto, H., Shimada, H., Oya, J., Hamanaka, A., \& Matsui, K. (2015). Surface subsidence due to underground mining operation under weak geological condition in Indonesia. Journal of Rock Mechanics and Geotechnical Engineering, 7(3), 337-344. https://doi.org/10.1016/j.jrmge.2015.01.007

Suchowerska, A. M., Merifield, R. S., \& Carter, J. P. (2013). Vertical stress changes in multi-seam mining under supercritical longwall panels. International Journal of Rock Mechanics and Mining Sciences, 61, 306-320. https://doi.org/10.1016/j.ijrmms.2013.02.009

Widodo, S., Oschmann, W., Bechtel, A., Sachsenhofer, R. F., Anggayana, K., \& Puettmann, W. (2010). Distribution of sulfur and pyrite in coal seams from Kutai Basin (East Kalimantan, Indonesia): Implications for paleoenvironmental conditions. International Journal of Coal Geology, 81(3), 151-162. https://doi.org/10.1016/j.coal.2009.12.003

Xu, T., Ranjith, P. G., Au, A. S. K., Wasantha, P. L. P., Yang, T. H., Tang, C. A., ... Chen, C. F. (2015). Numerical and experimental investigation of hydraulic fracturing in Kaolin clay. Journal of Petroleum Science and Engineering, 134, 223-236. https://doi.org/10.1016/j.petrol.2015.08.003

Zarlin, N., Sasaoka, T., Shimada, H., \& Matsui, K. (2012). Numerical study on an applicable underground mining method for soft extra-thick coal seams in Thailand. Journal of Engineering, 4(11), 739. https://doi.org/10.4236/eng.2012.411095 
Zipf, R. K. (2005). Failure mechanics of multiple seam mining interactions. Paper presented at the Ground Control in Mining, Morgantown, West Virginia.

\section{Copyrights}

Copyright for this article is retained by the author(s), with first publication rights granted to the journal.

This is an open-access article distributed under the terms and conditions of the Creative Commons Attribution license (http://creativecommons.org/licenses/by/4.0/). 